\title{
Parathyroid Carcinoma: Where We Stand
}

\author{
Raffaele Pezzani ${ }^{1,2 *}$ \\ ${ }^{1}$ OU Endocrinology, University of Padova, Italy \\ ${ }^{2}$ AIROB, Associazione Italiana per la Ricerca Oncologica di Base, Italy
}

Submission: April 21, 2017; Published: April 25, 2017

"Correspondence Address: Raffaele Pezzani, OU Endocrinology, DIMED, University of Padova, via Ospedale 105, 35128 Padova, Italy, Tel: +39 0498213018; Email: raffaele.pezzani@unipd.it

\section{Introduction}

Parathyroid carcinoma (PC) is a very rare endocrine malignancy, accounting for $1-5 \%$ of all cases of primary hyperparathyroidism (PHPT). PHPT is a sporadic disease, characterized by increased amounts of parathormone (PTH) levels that produces calcium excess in the blood Parathyroid carcinoma (hypercalcemia) [1,2]. In addition, PHPT can result as a part of familial disorders, such as hyperparathyroidismjaw tumor syndrome (HJTS) or multiple endocrine neoplasia type-1 or $2 \mathrm{~A}$ syndromes $[3,4]$. Due to its rarity, PC is still a great challenge for clinicians, also in considering the lack of concrete chemotherapeutic strategy. Indeed main treatment option for PC is surgery (en bloc resection, tumor debulking, metastasectomy), helped by loco regional treatments and radiotherapy. Surgery can be curative in many cases, but PC usually recurs after the first operation [5]. For recurrent, metastatic, progressive or unrespectable PC, novel target therapies are urgently needed.

Indeed chemotherapeutic regimens are based on anecdotal case reports results, in which association of vincristine/ cyclophosphamide/ actinomycin D, adriamycin/ cyclophosphamide/ 5-fluorouracil, dacarbazine (alone or associated with cyclophosphamide or 5 -fluorouracil) have been tried with very limited benefits [1]. Much work worldwide is in progress to study and deepen PC: Clinical Trials database query (words: parathyroid cancer) reported more than 170 results [6], underlining the importance of this cancer type, even if no study was specific for PC treatment. Only a small part of results explored the use of chemotherapeutics: 1 study is still recruiting, while 9 studies were completed. All studies analyzed the use of chemotherapy in several cancer types, including PC, but only 2 studies reported complete results, regrettably committed to investigate recurrent and metastatic head and neck cancer.

Both studies (in only one published work) revealed that the pre-specified progression free survival of 5.5 months was not achieved and the treatment-related deaths were higher than expected [6]. The other 7 studies did not report any outcome, again underlining a void in PC chemotherapy. From these small data, no clinical trial was designed to investigate chemotherapeutic regimen in PT, probably because of the rarity of the disease. It is known that the current chemotherapeutic strategies for cancer are essentially based on the use of combination regimen: at least in vitro this strategy is very promising and works Parathyroid carcinoma very well. Targeting different signaling pathways is probably the best approach we can adopt, especially when immunotherapy can be successfully associated. Indubitably, this approach is valid also for PC. However, given its rarity, in future only multi centric clinical trials can give a chance to develop novel therapeutic approaches, both at medical, surgical, radiological, biological or chemotherapeutic level. In the next few years, it is hoped that oncology/endocrine researchers all over the world will join their competences, energies, knowledge and expertise in order to fight against a cancer type, PT, still too lethal.

\section{Acknowledgement}

The author thanks AIROB (Associazione Italiana per la Ricerca Oncologica di Base) for participation in work design.

\section{Reference}

1. McClenaghan F, Qureshi YA (2015) Parathyroid cancer. Gland Surg 4(4): 329-338.

2. Rahbari R, Kebebew E (2011) Parathyroid tumors. In: DeVita VT Lawrence TS, Rosenberg SA (Eds.), Cancer: Principles and Practice of Oncology. ( $9^{\text {th }}$ edn). Philadelphia, Pa: Lippincott Williams \& Wilkins, pp 1473-1479.

3. Iacobone M, Masi G, Barzon L, Porzionato A, Macchi V, et al. (2009) Hyperparathyroidism-jaw tumor syndrome: a report of three large kindred. Langenbecks Arch Surg. 394(5): 817-825.

4. Sabbadin C, Donà G, Bordin L, Iacobone M, Camozzi V, et al. (2015) Transient hypercortisolism and symptomatic hyperthyroidism associated to primary hyperparathyroidism in an elderly patient: case report and literature review. BMC Endocr Disord 28(15): 4.

5. Wei CH, Harari A (2012) Parathyroid carcinoma: update and guidelines for management. Curr Treat Options Oncol 13(1):11-23. 


\section{Cancer Therapy \& Oncology International Journal}

6. Vermorken JB, Licitra L, Stöhlmacher-Williams J, Dietz A, Lopez-Picazo JM, et al. (2013) Phase II study of pemetrexed in combination with

This work is licensed under Creative Commons Attribution 4.0 License

DOI: $10.19080 /$ CTOIJ.2017.04.555646 cisplatin and cetuximab in recurrent or metastatic squamous cell carcinoma of the head and neck. Eur J Cancer 49(13): 2877-2883.

Your next submission with Juniper Publishers will reach you the below assets

- Quality Editorial service

- Swift Peer Review

- Reprints availability

- E-prints Service

- Manuscript Podcast for convenient understanding

- Global attainment for your research

- Manuscript accessibility in different formats

( Pdf, E-pub, Full Text, Audio)

- Unceasing customer service

Track the below URL for one-step submission https://juniperpublishers.com/online-submission.php 